\title{
Pulmonary Thromboendarterectomy Enabling Renal Transplantation in Patient of Chronic Kidney Disease: A Case Report
}

\author{
Kronik Böbrek Yetmezlikli Hastada Renal Transplantasyona Imkân \\ Sağlayan Pulmoner Tromboendarterektomi: Olgu Sunumu
}

Halil Ibrahim Yakar' , Asiye Kanbay ${ }^{2}$

\section{Abstract}

Pulmonary endarterectomy (PEA) is a surgical treatment approach for the treatment of patients with chronic thromboembolic pulmonary hypertension (CTEPH). The surgery is considered high risk in terms of mortality and morbidity. We present here a patient at high operative risk due to severe pulmonary hypertension (PH) and chronic renal failure (CKD). The 22year-old male patient was undergoing hemodialysis treatment for three years due to bilateral hydronephrosis-induced CKD, and was admitted to the hospital with increasing dyspnea. The diagnosis of CTEPH was made clinically and radiologically. During the follow-up period, an endarterectomy was planned, although the patient was considered high risk due to insufficient clinical response, despite medical therapy. Bilateral PEA was applied by thoracic surgery team. sPAP decreased from 105 to $35 \mathrm{mmHg}$ on echocardiography, and dyspnea was improved and functional capacity recovered after the PEA surgery. A renal transplantation was contraindicated in the preoperative period due to severe pulmonary arterial hypertension. PEA surgery was enabled to patient kidney transplantation due to an improvement in pulmonary functions and pulmonary artery pressure. We present here a case of CTEPH who had a chance of kidney transplantation after undergoing successful PEA surgery.

Key words: Chronic Thromboembolic Pulmonary Hypertension, Chronic Renal Failure, Pulmonary Endarterectomy.

\section{Özet}

Pulmoner endarterektomi (PEA), kronik tromboembolik pulmoner hipertansiyon (KTEPH) hastalarında cerrahi tedavi yöntemi olarak kullanılmaktadır. Diğer yandan mortalite ve morbiditesi yüksek bir cerrahidir. Burada ileri derece pulmoner hipertansiyonu (PH) bulunan, kronik böbrek yetmezliği (KBY) nedenli hemodialize giren ve bu nedenle yüksek riskle PEA yapılan bir olgu sunuldu. Yirmi iki yaşında erkek hasta, bilateral hidronefroza bağlı KBY nedeni ile 5 yıldır haftada 3 gün hemodialize girmekteydi. Giderek artan nefes darlığı nedeniyle hastaneye başvurdu. Klinik ve radyolojik olarak KTEPH tanısı konuldu. Takiplerinde medikal tedaviye rağmen yeterli klinik yanıt alınamaması nedeniyle hastaya yüksek riske rağmen pulmoner endarterektomi planlandı. Göğüs cerrahisi tarafından bilateral PEA operasyonu uygulandı. Hastanın kontrol ekokardiografisinde sPAP: 105 mmHg'dan 35 mmHg' a geriledi. Cerrahi sonrası takiplerinde hastanın istirahat dispnesi kayboldu, eforla dispne şikâyeti belirgin azaldı ve fonksiyonel kapasitesi arttı. Operasyon öncesi pulmoner hipertansiyon nedeniyle hastada renal transplantasyon kontrendike iken, postoperatif şikayetlerinin gerilemesi ve pulmoner arter basıncı düşmesi nedeniyle hastaya transplantasyon imkânı oluştu. Bu olgu sunumunda, başarılı bir PEA geçirdikten sonra böbrek nakli imkânı oluşan bir KTEPH hastası sunuldu.

Anahtar Sözcükler: Kronik Tromboembolik Pulmoner Hipertansiyon, Kronik Böbrek Yetmezliği, Pulmoner Endarterektomi.

'Tokat Gaziosmanpaşa Üniversitesi Tıp Fakültesi Göğüs Has talıkları Anabilim Dalı, Tokat

'Department of Chest Disease, Tokat Gaziosmanpasa University, Faculty of Medicine, Tokat, Turkey

${ }^{2}$ Istanbul Medeniyet Üniversitesi Tıp Fakültesi Göğüs Hastalıkları Anabilim Dali, İstanbul

Submitted (Başvuru tarihi): 15.12.2019 Accepted (Kabul tarihi): 04.02.2020

Correspondence (iletişim): Halil İbrahim Yakar, Tokat Gaziosmanpaşa Üniversitesi Tıp Fakültesi Göğüs Hastalıkla Anabilim Dalı, Tokat

e-mail: halil_yakar@hotmail.com 
Chronic thromboembolic pulmonary hypertension (CTEPH) is a disease with poor survival rates and increasing frequency (1). Recurrent and organized thrombi obliterate the pulmonary vascular system and cause progressive pulmonary hypertension and right heart failure. Pulmonary thromboendarterectomy (PEA) is the leading curative approach to $\mathrm{CTEPH}$, and can be life-saving in patients with severe pulmonary hypertension and proximal thrombus in the pulmonary arteries. In pulmonary endarterectomy operations, residual thrombus and fibrous obstructive tissue in the pulmonary arteries can be extracted under conditions of deep hypothermic circulatory arrest (2). In the postoperative period, pulmonary revascularization, a decrease in pulmonary artery pressure and clinical improvement can be expected due to the removal of thrombus tissue. That said, it is a surgical method associated with a high rate of mortality and morbidity $(3,4)$. We present here a patient considered a high surgical risk due to CRF prior to PEA, and who gained the possibility of renal transplantation after successful PEA surgery.

\section{CASE}

A 22-year-old male patient who had undergone hemodialysis three times a week for five years due to bilateral hydronephrosis, was admitted to our hospital with exercise dyspnea that had developed over the prior three months (Functional Capacity 3-4). Prominent pulmonary arteries and cardiomegaly were seen on chest X-ray (Figure 1), while p-pulmonale, right ventricular hypertrophy and right bundle branch block were seen on ECG (Figure 2). Echocardiography (ECO) revealed enlargement of the right heart cavity, severe pulmonary hypertension (sPAP: $105 \mathrm{mmHg}$ ) and paradoxical movement due to increased pressure in the interventricular septum. A Thorax CT angiography showed an enlargement of the main pulmonary artery and its branches, a nearly complete thrombus that obstructed the lumen, extending from the bilateral main pulmonary arteries to the segment branches, and also pneumonic infiltration in the right upper lobe (Figure 3). Anticoagulant therapy and antibiotherapy were initiated for CTEPH and pneumonia.

As a result of the insufficient clinical response to anticoagulant therapy, despite the three months of anticoagulant therapy, no clinical improvement was observed, and a PEA operation was planned, despite the high surgical risk. A bilateral pulmonary endarterectomy with median sternotomy under systemic hypothermia was successfully performed by the thoracic surgery team (Figure 4). In the control ECO, sPAP decreased to $35 \mathrm{mmHg}$.

In the postoperative follow-up, the patient's dyspnea complaint reduced considerably and functional capacity increased. The patient was referred to the Nephrology Unit for renal transplantation for CRF.

\section{DISCUSSION}

CTEPH is one of the leading causes of PHT (5). In patients with pulmonary artery pressure (PAP) exceeding 50 $\mathrm{mmHg}$, average five-year survival is reported to be $10 \%$ (6). CTEPH should be considered in the differential diagnosis of patients presenting with chronic dyspnea and/or chest pain. CTEPH should be investigated with a CT thorax angiography and echocardiography in such cases. Surgery is the optimum treatment for patients diagnosed with CTEPH (7), although PEA has a high risk of morbidity and mortality (8-10). Accordingly, medical treatment (oral anticoagulant, $C C B, E R A$, Riociguat, etc.) is preferred in patients with PAP $>50 \mathrm{mmHg}$ and in the presence of an additional disease that may increase the risk of postoperative mortality and morbidity $(11,12)$. OAC was initiated in our case due to sPAP: 105 (> 50) $\mathrm{mmHg}$ and CRF. However, the PEA operation was planned due to the patient's inability to respond to medical treatment and the patient's young age. While a renal transplant was contraindicated in the preoperative period due to PHT, a renal transplantation was possible due to the regression of the complaints, and the decrease in pulmonary artery pressure in the postoperative period.

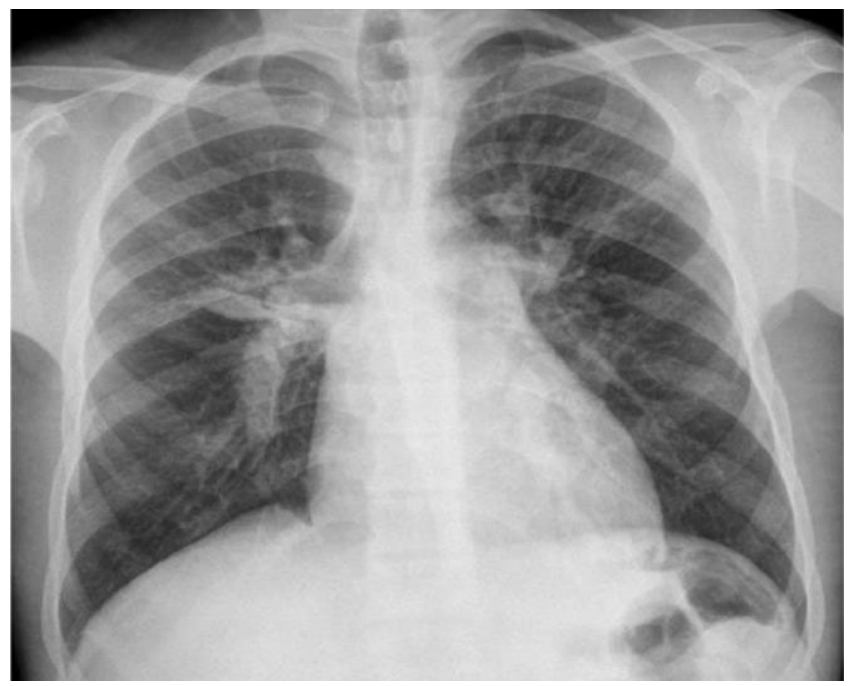

Figure 1: Initial Posteroanterior Chest $X$-ray (Bilateral pulmonary arteries were prominent, and pneumonic infiltration surrounded the vascular structures in the right upper lobe) 


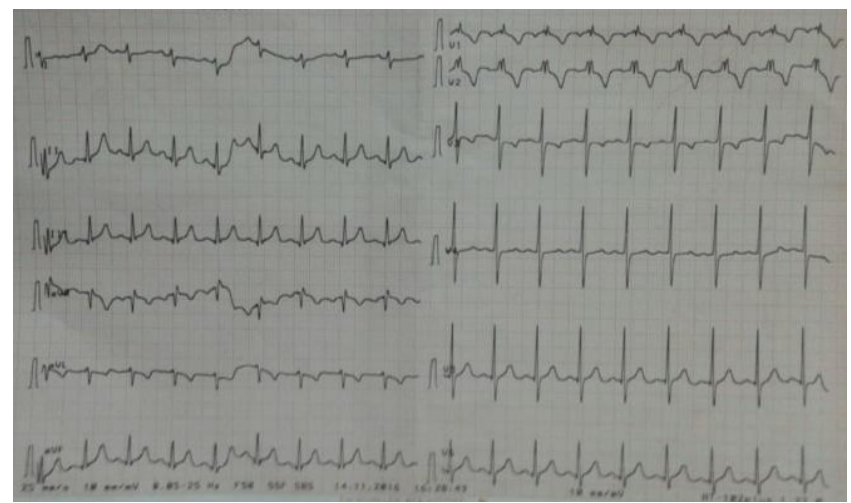

Figure 2: ECG: Right bundle branch block and right ventricular hypertrophy (V1-V2 RSR pattern, ST depression and T wave inversion on right precordial leads [V1-3])
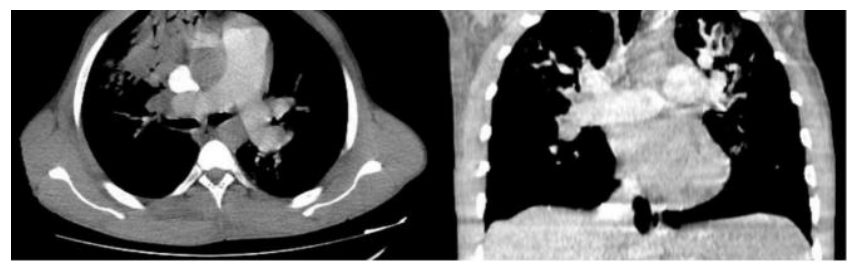

Figure 3: Axial and coronal section on thorax CT angiography. Enlargement of the main pulmonary artery and its branches, widespread thrombus obstructing the lumens, extending from the bilateral pulmonary arteries to the segment branches, and pneumonic infiltration of the right upper lobe were also observed

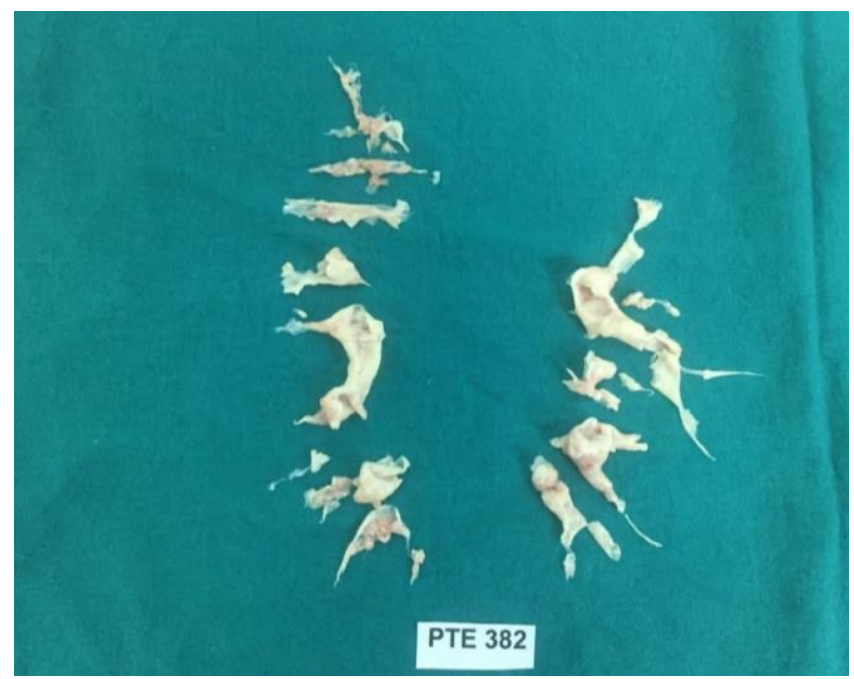

Figure 4: Postoperative view of thrombus material in the pulmonary artery branches

\section{CONCLUSION}

Pulmonary endarterectomy is a curative treatment for CTEPH. While renal transplantation was contraindicated in the preoperative period due to PHT, it became possible due to PEA in the postoperative period in our case. As such, PEA is thought to be important for survival in CTEP patients, and so all patients should carefully be evaluated for PEA.

\section{ABBREVIATIONS}

CTEPH: Chronic thromboembolic pulmonary hypertension, sPAB: systolic pulmonary artery pressure, PTE: Pulmonary thromboendarterectomy, CRF: Chronic renal failure, ECO: Echocardiography, ECG: Electrocardiography, OAC: Oral anticoagulant, PHT: Pulmonary Hipertension, ERA: Endothelin receptor antagonist, CKB: blockers.

\section{ACKNOWLEDGEMENT}

We thank Mr. Bedrettin Yildizeli for the patient's successful surgical operation.

\section{CONFLICTS OF INTEREST}

None declared.

\section{AUTHOR CONTRIBUTIONS}

Concept - H.I.Y., A.K.; Planning and Design - H.I.Y., A.K.; Supervision - H.I.Y., A.K.; Funding - H.I.Y.; Materials H.I.Y.; Data Collection and/or Processing - H.I.Y., A.K.; Analysis and/or Interpretation - H.I.Y., A.K.; Literature Review - H.I.Y.; Writing - H.I.Y.; Critical Review - H.I.Y., A.K.

\section{YAZAR KATKILARI}

Fikir - H.I.Y., A.K.; Tasarım ve Dizayn - H.I.Y., A.K.; Denetleme - H.I.Y., A.K.; Kaynaklar - H.I.Y.; Malzemeler H.I.Y.; Veri Toplama ve/veya İşleme - H.I.Y., A.K.; Analiz ve/veya Yorum - H.I.Y., A.K.; Literatür Taraması - H.I.Y.; Yazıyı Yazan - H.I.Y.; Eleştirel İnceleme - H.I.Y., A.K.

\section{REFERENCES}

1. Hyduk A, Croft JB, Ayala C, Zheng K, Zheng ZJ, Mensah GA. Pulmonary hypertension surveillance--United States, 1980-2002. MMWR Surveill Summ 2005; 54:1-28.

2. Sunar $H$, Yıldızeli $B$, Taş $S$, Yanartaş $M$, saçlı $H$, Kış $M$, et al. Pulmonary endarterectomy in chronic thromboembolic pulmonary hypertension. Turk Gogus Kalp Damar 2013; 21:7-13. [CrossRef]

3. Olman MA, Auger WR, Fedullo PF, Moser KM. Pulmonary vascular steal in chronic thromboembolic pulmonary hypertension. Chest 1990; 98:1430-4. [CrossRef]

4. Lee KC, Cho YL, Lee SY. Reperfusion pulmonary edema after pulmonary endarterectomy. Acta Anaesthesiol Sin 2001; 39:97-101.

5. Simonneau G, Robbins $I M$, Beghetti M, Channick RN, Delcroix M, Denton CP, et al. Updated clinical classifica- 
tion of pulmonary hypertension. J Am Coll Cardiol 2009; 30 (1 Suppl):S43-54. [CrossRef]

6. Riedel M, Stanek V, Widimsky J, Prerovsky I. Longterm follow-up of patients with pulmonary thromboembolism. Late prognosis and evolution of hemodynamic and respiratory data. Chest 1982; 81:151-8. [CrossRef]

7. Galié N, Humbert M, Vachiery JL, Gibbs S, Lang I,Torbicki A, et al. 2015 ESC/ERS Guidelines for the diagnosis and treatment of pulmonary hypertension: The Joint Task Force for the Diagnosis and Treatment of Pulmonary Hypertension of the European Society of Cardiology (ESC) and the European Respiratory Society (ERS): Endorsed by: Association for European Paediatric and Congenital Cardiology (AEPC), International Society for Heart and Lung Transplantation (ISHLT) Eur Heart J 2016;37:67-119. [CrossRef]

8. D'Armini AM, Zanotti G, Viganò M. Pulmonary endarterectomy: the treatment of choice for chronic thromboembolic pulmonary hypertension. Ital Heart J 2005; 6:8618.
9. Hagl C, Khaladj N, Peters T, Hoeper MM, Logemann F, Haverich $A$, et al. Technical advances of pulmonary thromboendarterectomy for chronic thromboembolic pulmonary hypertension. Eur J Cardiothorac Surg 2003; 23:776-81. [CrossRef]

10. Mellemkjaer S, Ilkjaer LB, Klaaborg KE, Christiansen CL, Severinsen IK, Nielsen-Kudsk JE, et al. Pulmonary endarterectomy for chronic thromboembolic pulmonary hypertension. Ten years experience in Denmark. Scand Cardiovasc J 2006; 40:49-53. [CrossRef]

11. Rubin LJ, Hoeper MM, Klepetko W, Galiè N, Lang IM, Simonneau G. Current and future management of chronic thromboembolic pulmonary hypertension: from diagnosis to treatment responses. Proc Am Thorac Soc 2006; 3:601-7. [CrossRef]

12. Ghofrani HA, D'Armini AM, Grimminger F, Hoeper MM, Jansa $\mathrm{P}$, Kim NH, et al. Riociguat for the treatment of chronic thromboembolic pulmonary hypertension. N Engl J Med 2013; 369:319-29. [CrossRef] 